\title{
Effects of Clearcutting on the Vegetation and Soil of a Sugar Maple-Dominated Ecosystem, Western Upper Michigan
}

\author{
DENNIS A. ALBERT and BURTON V. BARNES \\ School of Natural Resources, The University of Michigan, Ann Arbor, MI 48109-1115 (U.S.A.)
}

(Accepted 19 September 1986)

\begin{abstract}
Albert, D.A. and Barnes, B.V., 1987. Effects of clearcutting on the vegetation and soil of a sugar maple-dominated ecosystem, western Upper Michigan. For. Ecol. Manage., 18: 283-298.

The effects 50 years after clearcutting on the vegetation and soil of an ecosystem type dominated by sugar maple (Acer saccharum) were studied at four locations along the boundaries of the Sylvania Recreation Area (Ottawa National Forest) in western Upper Michigan, U.S.A. Commercially clearcut areas along the boundaries of the undisturbed 8500-ha tract enabled study of vegetation and soil in paired cut and uncut plots. Overstories of the clearcut plots exhibit increased stem densities and decreased basal area and stem diameters compared to those of uncut plots. Both the relative density of understory sugar maple and the total density of all understory trees decreased significantly on the clearcut plots. Groups of herbaceous species characteristic of the ground cover of the clearcut plots were identical to those found on the uncut plots.

There was no change in (1) thickness, mass, or total nutrient $\left(\mathrm{K}^{+}, \mathrm{Mg}^{2+}, \mathrm{Ca}^{2+}\right)$ contents of the forest floor, or (2) acidity of the upper horizons of the mineral soil. The exchangeable potassium levels in the upper horizons of the mineral soil decreased significantly, and also there was a decreasing trend in the levels of exchangeable calcium and magnesium.
\end{abstract}

\section{INTRODUCTION}

The Northern-Hardwoods forests of the western Great Lakes region of the United States are dominated by sugar maple (Acer saccharum L.); its associates include American beech (Fagus grandifolia Ehrh.), yellow birch (Betula alleghaniensis Britt.), basswood (Tilia americana L.), eastern hemlock (Tsuga canadensis (L.) Carr.), and other species depending on site conditions. These forests have been subjected to a number of harvesting methods - from individual tree selection to clearcutting (Westveld, 1949; Eyre and Zillgitt, 1953; Smith, 1962; Barrett, 1980). The term clearcutting is ambiguous and may mean the complete removal of all trees or only of all overstory trees (Tubbs, 1969). Allaged silviculture was recommended for bringing mature hardwood stands under 
management (Eyre and Zillgitt, 1953). However, millions of hectares of second-growth, northern hardwoods forests in this region are the result of commercial clearcutting that occurred in the first half of this century, beginning about 1900.

Clearcutting, as a method of regeneration, often has failed because adequate regeneration was not obtained following cutting (Metzger and Tubbs, 1971). According to Tubbs (1977), clearcutting is generally undesirable if timber is the management objective, whereas it is useful for wildlife browse and for converting the stand to less-tolerant species. Little published evidence is available concerning the long-term results of clearcutting forests of sugar maple, particularly with regard to species composition and soil nutrient status. Detailed investigations of landscape ecosystems in the Sylvania Recreation Area coupled with the finding of 50-year-old clearcut and uncut stands on the same ecosystem type provided a unique opportunity to study the effects of clearcutting without cut and uncut treatments being confounded by different site conditions. Thus, we wished to determine if there were, after 50 years, differences in soil and vegetative conditions between cut and uncut areas of the same ecosystem type.

The objectives of the study were: (1) to compare the physical and chemical properties of organic and mineral soil layers, and the vegetation of the adjacent cut and uncut areas of the Sugar Maple/Polygonatum ecosystem type, and (2) to compare the results with those found in a cut-uncut hemlock system (Hix and Barnes, 1984).

\section{STUDY AREA}

The Sylvania Recreation Area, $46^{\circ} 10^{\prime}$ to $46^{\circ} 15^{\prime} \mathrm{N}$ latitude and $89^{\circ} 14^{\prime}$ to $89^{\circ} 20^{\prime} \mathrm{W}$ longitude, is located in the western Upper Peninsula of Michigan in Gogebic County, along the border of Michigan and Wisconsin about $65 \mathrm{~km}$ southeast of Lake Superior. It is approximately 8500 ha in area.

The climate is predominantly continental in character, with only limited influence by Lake Superior. The region has a relatively short freeze-free period which averages 61 days per year. The average annual total precipitation, 864 $\mathrm{mm}$, is relatively well distributed throughout the year.

The bedrock formations underlying the Sylvania Recreation Area are either Lower or Middle Pre-Cambrian formations of the Laurentian Shield (Meshref and Hinze, 1970) and are predominantly granite and gneiss. Bedrock is overlain by a mantle of glacial deposits, in the range of 30-61 m thick (Thwaite, 1929; Doonan and Hendrickson, 1968). The deposits are characteristically reddish, acid, sandy loam with igneous, metamorphic, and reddish sandstone fragments (Jordan, 1973).

Sylvania is located almost entirely on the Watersmeet Moraine (Dorr and Eschman, 1970), which extends east-west across Gogebic County and contin- 
ues southward into Wisconsin. The moraine is primarily ice-stagnation (kettle-kame) topography, characterized by steep irregular ridges separated by kettle lakes, swamps, and bogs.

From 1980 to 1982, detailed studies of landscape ecology were conducted in the Sylvania Recreation Area to identify, map and describe the natural ecosystem types (Spies and Barnes, 1985a) by a multi-factor ecological approach that was modified from a system developed in Baden-Württemberg, West Germany. This system has been described (Schenker, 1964; Spurr and Barnes, 1980, pp. 324-329; Mühlhäusser et al., 1983; Barnes, 1984), and the results of its application in the Cyrus H. McCormick Experimental Forest (about 200 $\mathrm{km}$ northeast of Sylvania) have been published (Barnes et al., 1982; Pregitzer and Barnes, 1984).

A local ecosystem type, termed a site unit, is defined as a collection of individual sites that have: (1) similar physiography, soil, and vegetation; (2) similar silvicultural potential; (3) similar risk of damage from insects, diseases, and windthrow; and (4) similar growth and yield of forest trees (Barnes et al., 1982). A total of 25 ecosystems, 15 dryland and 10 wetland units, were identified and mapped. Upland ecosystems were dominated predominantly by hemlock or sugar maple (Spies and Barnes, 1985a). A previous study on hemlock-dominated ecosystems by Hix and Barnes (1984) showed marked differences in vegetation and soil nutrients between cut and uncut plots. Six ecosystems had sugar maple as a major component, the most prevalent of which was site unit 11: Well Drained, Light Sandy Loam on Moderately Steep Slopes; Sugar Maple/Polygonatum. It was located on gently to steeply sloping, undulating, ice-contact terrain, in either the mid- or upper-slope position. The slope averaged $14.5 \%$, and the length of slope averaged $70 \mathrm{~m}$. The typical landform was a moderately sloping broad ridge. Elevation above mean sea level (AMSL) ranged from 525 to $540 \mathrm{~m}$. The forest floor consists of a regular sequence of three horizons: the $\mathrm{Oi}(\mathrm{O} 1), \mathrm{Oe}(\mathrm{O} 2 \mathrm{f})$, and $\mathrm{Oa}(\mathrm{O} 2 \mathrm{~h})$. In the classification system of Hoover and Lunt (1952), the forest floor of both the uncut and clearcut plots would be classified as a thin mor because of the presence of an Oa less than $1 / 2$-in $(12.7-\mathrm{mm})$ thick. The thin $\mathrm{Oa}$ layer contrasts strongly with the thick $0 \mathrm{a}$ of adjacent hemlock ecosystems.

The mineral soil is classified as a coarse-loamy, mixed, frigid, Alfic Fragiorthod. The soil is well drained, with no mottling occurring within $1 \mathrm{~m}$ of the surface. The water table was below $150 \mathrm{~cm}$. A fragipan was commonly present below the Bs horizon.

The ecosystem is dominated by sugar maple in the overstory. Typical herbaceous ground-cover species include Dryopteris intermedia (Muhl. ex Willd.) A. Gray, Streptopus roseus Michx., Polygonatum pubescens (Willd.) Pursh, and Lycopodium dendroideum Michx. The most common shrub is Dirca palustris $\mathrm{L}$.

The most widely occurring ecosystem dominated by hemlock was site unit 
9: Well Drained, Extremely Acid Sandy Loam on Moderate Slopes; Hemlock/Clintonia (Hix and Barnes, 1984). Comparisons between the soil, topography, and vegetation of the sugar maple and the hemlock ecosystems will be made in the Discussion. Some of the major differences between the ecosystems follow. Typically, the hemlock ecosystem occurred on different terrain and displayed different soil development than the sugar maple ecosystem. The slope angle of the hemlock ecosystem averages $6 \%$, whereas the sugar maple ecosystem has steeper slopes, averaging $9 \%$ and as steep as $30 \%$. The hemlock ecosystem is typically found on west and south aspects and on low ridges and hummocky areas adjacent to wetlands. The sugar maple ecosystem is found on all aspects, over a broad range of slope positions.

\section{METHODS}

\section{Field methods}

Areas of site unit 11 were located by inspection of aerial photographs and field reconnaissance. Four areas along the boundaries of the Sylvania Recreation Area, each greater than 0.5 square mile $\left(\approx 1.3 \mathrm{~km}^{2}\right)$ in area, with no apparent differences in physiography between the uncut and clearcut areas were selected for the study. Portions of all the boundaries of Sylvania were cutting lines, with the area outside clearcut and the area inside Sylvania undisturbed except for localized cutting of white pine (Pinus strobus L.). Two 15 $\times 30$-m plots were established on the uncut area and two plots on the adjacent clearcut area in each of the four areas. The clearcut and uncut plots were located within $100 \mathrm{~m}$ of the boundary line. The four areas selected for sampling were representative of site unit 11 , and because of the proximity of the clearcut to the uncut areas, similar site and vegetation conditions prior to cutting were assumed. There were no cutting records because the land was privately owned. No evidence was found to indicate that the clearcut and uncut areas were significantly different from one another before cutting. Similar slope angles, aspects, and soil textures existed on both the cut and uncut sample plots.

An additional site unit 11 stand, clearcut in the spring of 1981, was studied for comparison to the uncut and earlier clearcut plots. This plot was located near the northeast boundary of Sylvania.

The overstory, understory, and ground-cover vegetation were sampled. Species nomenclature was based on the following sources: trees and shrubs (Barnes and Wagner, 1981), herbaceous dicots (Fernald, 1950), monocots (Voss, 1972), and ferns (Mickel, 1979). The dbh (diameter at $1.3 \mathrm{~m}$ above ground) of all overstory trees $(10-\mathrm{cm}$ dbh class or greater) and the dbh class of all understory trees $(2.5-\mathrm{cm}, 5.0-\mathrm{cm}$, and $7.5-\mathrm{cm}$ dbh classes ) were recorded for each plot. The percent coverage of all ground-cover species (both herbaceous and woody) was estimated by class for those species that occurred throughout the center 
TABLE 1

The cover-class scale used in estimating the coverage of species in sample plots

\begin{tabular}{lccc}
\hline Cover class & \multicolumn{3}{l}{ Range of cover $(\%)$} \\
\hline 0.25 & Trace & - & 0.005 \\
0.50 & 0.005 & - & 0.01 \\
1 & 0.01 & - & 0.1 \\
2 & 0.1 & - & 0.5 \\
3 & 0.5 & - & 1.0 \\
4 & 1.0 & - & 2.0 \\
5 & 2.0 & - & 4.0 \\
6 & 4.0 & - & 8.0 \\
7 & 8.0 & - & 16.0 \\
8 & 16.0 & - & 32.0 \\
9 & 32.0 & - & 64.0 \\
10 & 64.0 & - & 100.0 \\
\hline
\end{tabular}

$5 \times 30$-m strip (Spies and Barnes, 1985a). The center strip refers to the central $5 \times 30-\mathrm{m}$ portion of each $15 \times 30-\mathrm{m}$ rectangular plot. Twelve cover classes, modified from those used by Hix (1983) in the study of the hemlock ecosystem, were used (Table 1). Total height of three or more overstory dominants were measured with a clinometer. The approximate date of clearcutting was estimated on the clearcut plots by boring one or more dominant or co-dominant trees of various species with an increment borer.

Soil profile data were collected from a representative soil pit on each plot according to standard soil survey procedures (Anonymous, 1951). Soil samples were collected from each horizon of each soil pit for laboratory analyses. Forest floor samples were collected by horizon $(\mathrm{Oi}, \mathrm{Oe}, \mathrm{Oa})$ from the approximate center of each of nine $5 \times 10-\mathrm{m}$ subplots, and then combined systematically into three samples per plot, i.e., samples to the left and right of each of the three central $5 \times 10-\mathrm{m}$ subplots were combined with their respective center subplot.

\section{Laboratory analyses and data}

Particle-size distribution of the mineral soil samples was determined using the hydrometer method of Day (1965), as modified by Grigal (1973). $\mathrm{pH}$ was determined with a glass electrode in water using a soil-water ratio of $1: 1(\mathrm{w} / \mathrm{v})$. Organic carbon was determined by the Walkley-Black method (Allison, 1965). Organic matter (percent) in the mineral soil was considered to be total carbon multiplied by a conversion factor of 1.72 (Broadbent, 1965). After extraction with ammonium acetate, exchangeable $\mathrm{Ca}, \mathrm{Mg}$ and $\mathrm{K}$ determinations were made on a Perkin-Elmer atomic absorption spectrophotometer model 403. Soil 
bulk density was determined for the upper $30 \mathrm{~cm}$ of each plot from samples collected with a Volumeasure cylinder.

Forest floor samples were oven-dried and weighed. Woody materials greater than $2 \mathrm{~cm}$ in any dimension were removed from each sample in order to represent the nutrient status of the forest-floor horizons more accurately (Quesnel and Lavkulich, 1981). Samples were then ground in a Wiley mill (20-mesh sieve ) $\mathrm{pH}$ was determined with a glass electrode in water using a sample:water ratio of $1: 1(\mathrm{v} / \mathrm{v})$. One-gram subsamples were then ashed in a muffle oven, and total cations were extracted from the ashed subsamples with $5 \mathrm{~mL}$ of $20 \%$ $\mathrm{HCl}$ solution. Organic matter in each forest-floor sample was considered to be the oven-dry weight $(1 \mathrm{~g})$ minus the ash content. $\mathrm{Ca}, \mathrm{Mg}$ and $\mathrm{K}$ determinations were made on an atomic absorption spectrophotometer. Nutrient concentrations are expressed on an ash-free, dry mass basis (i.e., as a percent of organic matter mass) to avoid sample weight variations caused by mineral soil contamination.

Data on soil texture, collected and analyzed by horizon, were transformed to a weighted average for the $1-30 \mathrm{~cm}$ depth interval. This transformation was necessary to standardize the data among the different plots, as each plot had slightly different thicknesses of the major horizons of its soil profile.

For each forest-floor variable, the mean of the three combined samples of each of the forest-floor horizons ( $\mathrm{Oi}, \mathrm{Oe}, \mathrm{Oa})$ was used in the analyses. The variables (except for $\mathrm{pH}$, ash content, and bulk density) representing the total forest floor were the sum of the means of the individual horizons.

Relative density (percent) was computed by summing the total number of stems on a plot for a species and dividing by the total number of stems of all species on the plot. Relative dominance (percent) was computed in the same manner using basal area instead of the number of stems.

Cover-class values were used to indicate the abundance of ground-cover species in all analyses. Species occurring outside the center strip, but within the overall plot, were coded as 0.25 . A cover-class value for each ecological species group was obtained by dividing the total coverage of the group for each plot by the number of species of the group. An ecological species group is a collection of ground-cover plants that indicates a certain set of environmental conditions such as soil moisture, soil fertility, or light (Barnes et al., 1982; Spies and Barnes, 1985b). Only species which occurred in at least three of the $15 \times 30-\mathrm{m}$ plots were used in the analyses. The presence of one member of a species group was the basis for including the species group in canonical variates and principal component analyses.

Sampling was conducted in August 1981 within a site unit 11 stand that had been clearcut during the early summer of 1981 . The 1981 clearcut plot was subsequently sampled each year from 1982 through 1985.

The statistical computer programs (MIDAS) of the Statistical Research Lab of the University of Michigan were used to analyze the data. Two-way 
analysis of variance (fixed-effects design) was used to test for differences in physiography, forest floor, soil, overstory, and understory variables. A-priori $F$-tests at the $5 \%$ level of significance were used to test for differences in the means of the variables; $P$-values are included in the text where appropriate. As a test for normality, the distributions of these variables were examined in histograms, and skewness and kurtosis were computed for each. These analyses indicated that the distributions did not significantly depart from normality in most cases. The Kruskal-Wallis nonparametric test (Conover, 1980) at the $10 \%$ level of significance was used to determine differences in the coverage of a ground-cover species or of an ecological species group between the uncut and clearcut plots.

\section{RESULTS}

\section{History}

Commercial clearcutting in the four areas occurred approximately $47,49,53$, and 53 years ago, an average of 50 years before the 1982 field season. Clearcutting probably removed all merchantable trees to a diameter limit of $20-25 \mathrm{~cm}$.

Fire, thought to be a factor responsible for the establishment of hemlock stands in some areas (Maissurow, 1941; Goff, 1967), and indicated by fire scars in many of the hemlock cores from site unit 9 (Hix and Barnes, 1984), does not appear to be a common occurrence in sugar maple-dominated site unit 11. On the cut and uncut plots dominated by sugar maple, none of the cored hemlock, red maple (Acer rubrum L.), or yellow birch trees had fire scars. Although charcoal was common in the forest floor of the hemlock ecosystem (Hix and Barnes, 1984), no charcoal was found in the forest floor of the sugar maple ecosystem. Windthrow appears to be the most common source of disturbance in sugar maple-dominated ecosystems, as indicated by the presence of windthrow mounds throughout Sylvania and on almost all sample plots. Deer browse of ground-cover vegetation was also a common source of disturbance.

\section{Vegetation}

Overstory, understory, and tree seedlings. Clearcutting resulted in no statistically significant changes in the overstory composition of site unit 11 (Table 2 ). The average total overstory basal area of the clearcut plots was significantly less ( 28.0 vs. $41.3 \mathrm{~m}^{2} / \mathrm{ha}$ ) and the average overstory density (number of stems per ha) was significantly greater (577.7 vs. 380.5$)$ than that of the uncut plots 50 years after clearcutting (Table 2 ).

The average number of small overstory trees (less than $30 \mathrm{~cm} \mathrm{dbh}$ ) was significantly higher ( 20.8 vs. 6.6$) 50$ years after clearcutting. The ratio of the 


\section{TABLE 2}

Average basal area, relative density ${ }^{a}$, and relative dominance ${ }^{a}$ of overstory ${ }^{b}$ species of the uncut and clearcut plots of site unit 11, a sugar maple-dominated ecosystem of the Sylvania Recreation Area, Upper Michigan.

\begin{tabular}{|c|c|c|c|c|c|}
\hline \multirow[t]{2}{*}{ Species and variables } & \multicolumn{2}{|l|}{$\begin{array}{l}\text { Uncut } \\
(n=8)\end{array}$} & \multicolumn{3}{|c|}{$\begin{array}{l}\text { Clearcut } \\
(n=8\end{array}$} \\
\hline & Mean & S.D. & Mean & & S.D. \\
\hline \multicolumn{6}{|l|}{ Acer saccharum } \\
\hline basal area $\left(\mathrm{m}^{2} / \mathrm{ha}\right)$ & $30.1 \pm$ & $=7.0$ & 21.4 & \pm & 5.8 \\
\hline relative density (\%) & $74.7 \pm$ & 19.7 & 84.0 & \pm & 11.7 \\
\hline relative dominance $(\%)$ & $75.6 \pm$ & 21.4 & 77.1 & \pm & 22.5 \\
\hline \multicolumn{6}{|l|}{ Betula alleghaniensis } \\
\hline basal area $\left(\mathrm{m}^{2} / \mathrm{ha}\right)$ & $5.4 \pm$ & 6.7 & 4.1 & & 4.4 \\
\hline relative density $(\%)$ & $3.5 \pm$ & 4.2 & 9.3 & \pm & 7.2 \\
\hline relative dominance $(\%)$ & $11.5 \pm$ & 13.3 & 14.2 & \pm & 14.4 \\
\hline \multicolumn{6}{|l|}{ Tsuga canadensis } \\
\hline basal area $\left(\mathrm{m}^{2} / \mathrm{ha}\right)$ & $3.2 \pm$ & 4.0 & 1.8 & & 2.5 \\
\hline relative density (\%) & $14.8 \pm$ & 18.1 & 4.1 & \pm & 6.3 \\
\hline relative dominance $(\%)$ & $7.3 \pm$ & 8.7 & 6.0 & \pm & 8.4 \\
\hline \multicolumn{6}{|l|}{ Tilia americana } \\
\hline basal area $\left(\mathrm{m}^{2} / \mathrm{ha}\right)$ & $1.8 \pm$ & 2.8 & 0.5 & & 0.9 \\
\hline relative density $(\%)$ & $5.0 \pm$ & 7.6 & 1.3 & \pm & 2.5 \\
\hline relative dominance $(\%)$ & $3.8 \pm$ & 5.6 & 1.7 & \pm & 3.2 \\
\hline \multicolumn{6}{|l|}{ Acer rubrum } \\
\hline basal area $\left(\mathrm{m}^{2} / \mathrm{ha}\right)$ & $0.8 \pm$ & 2.2 & 0.4 & \pm & 0.1 \\
\hline relative density (\%) & $0.5 \pm$ & 1.4 & 0.7 & \pm & 2.0 \\
\hline relative dominance $(\%)$ & $1.6 \pm$ & 4.5 & 0.1 & \pm & 0.4 \\
\hline \multicolumn{6}{|l|}{ Ostrya virginiana } \\
\hline basal area $\left(\mathrm{m}^{2} / \mathrm{ha}\right)$ & $0.1 \pm$ & 0.2 & 0.2 & \pm & 0.6 \\
\hline relative density (\%) & $1.5 \pm$ & 2.8 & 0.6 & \pm & 1.7 \\
\hline relative dominance $(\%)$ & $0.2 \pm$ & 0.4 & 0.8 & \pm & 2.1 \\
\hline \multicolumn{6}{|l|}{ Total overstory } \\
\hline basal area $\left(\mathrm{m}^{2} / \mathrm{ha}\right)$ & $41.3 \pm$ & $\pm 8.7^{*}$ & 28.0 & \pm & $2.1^{*}$ \\
\hline density (No. stems per ha) & $380.5 \pm$ & $\pm 93.1^{*}$ & 577.7 & \pm & $184.4^{*}$ \\
\hline
\end{tabular}

*Means followed by an asterisk (*) are different between the uncut and clearcut plots at the 0.05 level of significance (ANOVA).

a Relative density is expressed in relative numbers of stems. Relative dominance is expressed in relative amount of basal area.

${ }^{\mathrm{b}}$ Overstory $=$ stems $>9 \mathrm{~cm}$ dbh.

average number of small trees to large trees was statistically greater (4.2 vs. 0.7 ) on the clearcut plots.

The total density of understory trees was reduced significantly (76\%) by clearcutting (Table 3 ). The relative density of sugar maple increased signifi- 
TABLE 3

Average density and relative density of understory ${ }^{a}$ species of the uncut and clearcut plots of site unit 11, a sugar maple-dominated ecosystem of the Sylvania Recreation Area, Upper Michigan

\begin{tabular}{|c|c|c|c|c|}
\hline \multirow[t]{2}{*}{ Species } & \multicolumn{2}{|c|}{$\begin{array}{l}\text { Uncut } \\
(n=8)\end{array}$} & \multicolumn{2}{|c|}{$\begin{array}{l}\text { Clearcut } \\
(n=8)\end{array}$} \\
\hline & Mean & S.D. & Mean & S.D. \\
\hline \multicolumn{5}{|l|}{ Acer saccharum } \\
\hline density (No. stems per ha) & 561.0 & $\pm 412.9^{*}$ & 172.2 & $\pm 102.7^{*}$ \\
\hline relative density $(\%)$ & 85.0 & $\pm \quad 34.5$ & 98.2 & $\pm \quad 5.0$ \\
\hline \multicolumn{5}{|l|}{ Ostrya virginiana } \\
\hline density (No. stems per ha) & 19.4 & 25.0 & 2.8 & 7.8 \\
\hline relative density $(\%)$ & 2.1 & 2.8 & 1.8 & 5.0 \\
\hline \multicolumn{5}{|l|}{ Tsuga canadensis } \\
\hline density (No. stems per ha) & 2.8 & 7.9 & & \\
\hline relative density $(\%)$ & 12.5 & $\pm \quad 35.4$ & & \\
\hline \multicolumn{5}{|l|}{ Acer rubrum } \\
\hline density (No. stems per ha) & 2.8 & 7.9 & & \\
\hline relative density $(\%)$ & 0.4 & $\pm \quad 1.0$ & & \\
\hline Total density (No. stems per ha) & 586.0 & $\pm 427.6^{*}$ & 175.0 & \pm 101.8 \\
\hline
\end{tabular}

${ }^{*}$ Means followed by an asterisk $\left({ }^{*}\right)$ are different between the uncut and clearcut plots at the 0.05 level of significance (ANOVA).

${ }^{\mathrm{a}}$ Understory $=1.5 \mathrm{~cm}<$ stems $<9.0 \mathrm{~cm} \mathrm{dbh}$.

cantly, from $85 \%$ to $98 \%, 50$ years after clearcutting, and neither red maple nor hemlock was present on any of the four locations following clearcutting.

No significant difference existed between the number or species of tree seedlings present in the ground cover of the uncut and clearcut plots. Sugar maple, the most common seedling in the uncut plots, remained the most common in the clearcut plots.

Ecological species groups. Of the twelve ecological species groups recorded in the groundcover of the 16 uncut and clearcut plots, only one, the Dryopteris group, increased its coverage significantly. The number of occurrences of Carex leptonervia Fern., a species of sedge within this species group, increased from 3 on the uncut plots to 5 on the clearcut plots; a $300 \%$ increase of coverage was also found.

Forest floor

A significant increase in the mass of the forest floor resulted from clearcutting (Table 4). No significant differences in the $\mathrm{pH}$ or nutrients ( $\mathrm{Ca}, \mathrm{Mg}$ and $\mathrm{K})$ were found. 
TABLE 4

Average physical and chemical properties for the $\mathrm{Oi}, \mathrm{Oe}$, and $\mathrm{Oa}$ horizons and total forest floor of the uncut and clearcut plots of site unit 11, a sugar maple-dominated ecosystem of the Sylvania Recreation Area, Upper Michigan

\begin{tabular}{|c|c|c|c|c|c|c|c|c|}
\hline \multirow[t]{2}{*}{ Property } & \multicolumn{4}{|c|}{$\begin{array}{l}\text { Uncut } \\
(n=8)\end{array}$} & \multicolumn{4}{|c|}{$\begin{array}{l}\text { Clearcut } \\
(n=8)\end{array}$} \\
\hline & $\mathrm{Oi}$ & $\mathrm{Oe}$ & $\mathrm{Oa}$ & Total & Oi & $\mathrm{Oe}$ & $\mathrm{Oa}$ & Total \\
\hline Thickness (cm) & 3.06 & 1.44 & 1.56 & 6.06 & 3.54 & 1.25 & 1.54 & 6.33 \\
\hline Ash content (\%) & 16.85 & 25.62 & 58.24 & & 16.30 & 25.72 & 65.09 & \\
\hline pH & 4.77 & 4.92 & 4.46 & & 4.69 & 4.60 & 4.20 & \\
\hline Bulk density $\left(\mathrm{g} / \mathrm{cm}^{3}\right)$ & 0.01 & 0.09 & 0.07 & & 0.01 & 0.11 & 0.08 & \\
\hline Mass (t/ha) & 4.44 & 10.40 & 11.62 & $26.46^{*}$ & 4.10 & 11.93 & 13.14 & $29.17^{*}$ \\
\hline Potassium ( $\mathrm{kg} / \mathrm{ha})$ & 5.03 & 9.40 & 10.13 & 24.56 & 4.59 & 12.04 & 10.12 & 26.75 \\
\hline Magnesium (kg/ha) & 5.23 & 12.90 & 12.14 & 30.27 & 4.92 & 15.03 & 12.42 & 32.37 \\
\hline Calcium (kg/ha) & 85.40 & 189.97 & 89.91 & 365.28 & 75.08 & 175.02 & 81.98 & 332.08 \\
\hline
\end{tabular}

*Means followed by an asterisk (*) are different between the uncut and clearcut plots at the 0.05 level of significance (ANOVA).

\section{Mineral soil}

No significant differences in the soil horizons, $\mathrm{pH}$, or texture of the upper $30 \mathrm{~cm}$ of the mineral soil were found between cut and uncut plots (Table 5). Similarly, none of these factors changed significantly between 30 and $100 \mathrm{~cm}$ in depth. The level of $\mathrm{K}$ decreased significantly for the upper $10 \mathrm{~cm}, 20 \mathrm{~cm}$, and $30 \mathrm{~cm}$ after clearcutting, with a $28 \%$ decrease of in the upper $30 \mathrm{~cm}$ of soil. A similar but nonsignificant trend in reduced nutrient levels in the upper 30

\section{TABLE 5}

Average physical and chemical properties for the upper 10,20 , and $30 \mathrm{~cm}$ of the mineral soil of the uncut and clearcut plots of site unit 11, a sugar maple-dominated ecosystem of the Sylvania Recreation Area, Upper Michigan

\begin{tabular}{lccccccc}
\hline Property & \multicolumn{2}{l}{$\begin{array}{l}\text { Uncut } \\
(n=8)\end{array}$} & \multicolumn{5}{l}{$\begin{array}{l}\text { Clearcut } \\
(n=8)\end{array}$} \\
\cline { 2 - 4 } \cline { 6 - 8 } & $0-10 \mathrm{~cm}$ & $0-20 \mathrm{~cm}$ & $0-30 \mathrm{~cm}$ & & $0-10 \mathrm{~cm}$ & $0-20 \mathrm{~cm}$ & $0-30 \mathrm{~cm}$ \\
\hline $\mathrm{pH}$ & 4.27 & 4.28 & 4.31 & & 4.15 & 4.19 & 4.22 \\
Organic matter (t/ha) & 17.21 & 37.49 & 53.36 & & 15.97 & 35.14 & 51.78 \\
Bulk density (g/cm $\left.{ }^{3}\right)$ & 1.34 & 1.34 & 1.26 & & 1.37 & 1.32 & 1.30 \\
Potassium (kg/ha) & $40.86^{*}$ & $74.45^{*}$ & $101.58^{*}$ & & $30.66^{*}$ & $54.46^{*}$ & $72.96^{*}$ \\
Magnesium (kg/ha) & 60.71 & 111.42 & 149.49 & & 49.26 & 87.70 & 111.29 \\
Calcium $(\mathrm{kg} / \mathrm{ha})$ & 588.36 & 1061.00 & 1399.90 & & 450.48 & 782.21 & 1052.50 \\
\hline
\end{tabular}

*Means followed by an asterisk $\left({ }^{*}\right)$ are different between the uncut and clearcut plots at the 0.05 level of significance (ANOVA). 
$\mathrm{cm}$ of soil was found for $\mathrm{Ca}(25 \%$ decrease; $P<0.08)$ and $\mathrm{Mg}$ ( $26 \%$ decrease; $P<0.11$ ) on the cut plots.

\section{DISCUSSION}

\section{Vegetation - Overstory}

Site unit 11 was dominated by sugar maple prior to commercial clearcutting. Fifty years following clearcutting, it remains the dominant species in the overstory. All of the tree species present in the overstory prior to cutting were present in the overstory after clearcutting (Table 2 ). The relative density of yellow birch increased from 3.5 to $9.3 \%(P<0.06)$ (Table 2$)$. This biologically noteworthy increase was probably due both to the disturbance of the forest floor during cutting and to increased light levels in the ground and understory of the clearcut stand. Increment cores of yellow birch indicated that with the exception of occasional residual trees (large commercially undesirable trees left by loggers), all of the yellow birch in the overstory had established shortly after the time of clearcutting. Only the residual trees showed any sign of release, and the time of release agreed with that seen in the hemlock ecosystem. All yellow birches which established after clearcutting were subdominant to the sugar maple canopy trees and due to light requirements may not survive the next $30-50$ years.

The relative density of hemlock in the overstory was somewhat lower $(P<0.14)$ in the clearcut plots. Seventeen hemlocks were present on six of eight uncut plots, whereas only five hemlocks were present on two of eight cut plots. Although the decrease of hemlock is not significantly lower in the clearcut plots no hemlocks regenerated after clearcutting. Hix and Barnes (1984) found little hemlock reproduction following clearcutting even in hemlockdominated ecosystems. Increment cores of the hemlocks present in the clearcut plots indicate that all the hemlock stems were present prior to clearcutting. Hemlocks on the cut plots had been understory or small overstory trees prior to clearcutting. The growth rates of the hemlocks were higher following clearcutting than prior to cutting, indicating that mature hemlock responded well to release (Marshall, 1927). Growth rates of hemlock decreased 20-50 years following clearcutting as stand density increased.

Clearcutting has produced high-quality pole-sized sugar maple and yellow birch trees with straight boles and few branches on the lower portion of the bole. The relative density of yellow birch, a valuable timber species, is higher on the clearcut stands than on the uncut stands. Clearcutting provides the light levels necessary for successful yellow birch regeneration (Winget et al., 1965). However, the yellow birch may not survive to harvestable size because of decreasing light in the maturing sugar maple stand.

Clearcutting of this previously uncut forest produced a well stocked sugar 
maple stand of reasonably good quality. However, a second clearcutting of the current stand is unlikely to accomplish the same result because of the lack of advanced regeneration. Based on the present size structure of trees in the clearcut plots and typical growth rates for sugar maple (Solomon, 1977), approximately $55 \%$ of the present overstory trees on the clearcut plots were understory trees or seedlings at the time the stands were cut. The clearcut plots now contain only $30 \%$ as many understory trees as the adjacent uncut plots, and large sugar maple seedlings are rare in the groundcover layer. The lack of understory and large seedlings on the cut plots is probably the result of low light levels below the dense canopy of sugar maples that developed after clearcutting. Although small seedlings are common, they seldom survive to reach the understory or overstory.

Commercial clearcutting of forest stands with inadequate advanced regeneration often results in poorly stocked, patchy stands with heavy competition from grasses and shrubs (Metzger and Tubbs, 1971). The 1981 clearcut plot exhibits this stocking problem. Although this cutover stand contained approximately 422 understory stems per ha in 1981 (two and a half times the number on the average clearcut plot), mortality in just 4 years reduced the understory to 311 stems per ha (a $26 \%$ decrease) by 1985 . Dense thickets of red raspberry (Rubus idaeus L.) covered approximately $50 \%$ of the plot, and very few sugar maple seedlings over $1 \mathrm{~m}$ tall were present. Thus, even with an initial understory density of 400 stems per ha, clearcutting of second-growth sugar maple forests is likely to produce understocked stands with low productivity.

Vegetation - Understory

The understory of the clearcut plots was dominated by sugar maple, with a 98\% relative density (Table 3 ). Hemlock and red maple, both present at low levels in the uncut plots, were absent in the clearcut plots. Yellow birch trees were absent in the understory of both the uncut and the clearcut plots. Yellow birch was seldom present as a seedling in either the cut or uncut plots.

\section{Vegetation - Groundcover}

Conditions do not typically appear to be favorable for the establishment of many tree species in uncut or clearcut sugar maple forests. Although mature hemlock, red maple and northern white-cedar (Thuja occidentalis L.) trees are all present in the wetlands adjacent to site unit 11, no seedlings of these species were found in either the cut or uncut plots. Hemlock stands similarly showed understory dominance by sugar maple following clearcutting ( Hix and Barnes, 1984), but red maples and yellow birches were also abundant.

Carex leptonervia was present in significantly greater levels on the clearcut plots. Yearly examination between 1981 and 1985 of the sugar maple plot that 
had been cut in 1981 indicated that sedge coverage increased greatly following clearcutting. Thus, it appears that $C$. leptonerva is able to maintain its high coverage for at least 50 years.

Fifty years after clearcutting, there was no significant difference between the number of ground-cover species on the cut (21.6) and uncut (19.9) plots. In contrast, the number of species on the 1981 clearcut sugar maple plot (43) was statistically higher than the number of species on either the uncut plots or the clearcut plots. Yearly sampling of the ground-cover vegetation of the 1981 clearcut plot from 1981 to 1985 indicates that the number of species increased immediately following cutting, and continued to increase through 1983 (43 in 1981 to 48 in 1983). Many of the species present on the 1981 clearcut plot require high levels of light. By August of 1984 three of the species with high light demands, Tragopogon pratensis L., Taraxacum officinale Weber, and Verbascum thapsus $\mathrm{L}$., were greatly reduced in coverage as the understory canopy began to become more dense. Similar short-term changes in the ground-cover flora probably occurred on the sugar maple plots which were clearcut 50 years ago.

Clearcutting of hemlock had a much greater effect on ground-cover vegetation (Hix and Barnes, 1984). Three species present in uncut stands were absent in the cut stands, whereas 18 new species established and persisted in cut stands over the 50-year period since clearcutting, six on a statistically significant number of plots. After cutting, the highly acid, nutrient-poor, drought-prone hemlock litter becomes covered with less-acid and more nutrient-rich hardwood leaves, that in part may be responsible for the establishment of a large number of new ground-cover species. Moisture conditions also improve, allowing more moisture-demanding species to establish. In contrast, the forest floor of the sugar maple-dominated ecosystem is more well buffered from such drastic changes so that changes in vegetation appear minor 50 years after cutting.

Soils

The quantity of organic material was significantly higher on the cut plots; the absolute amount is a $10 \%$ increase (Table 4). A possible explanation for the increased mass of the forest floor on the sugar maple plots is the slow decomposition and incorporation into the forest floor of the large amount of slash produced during clearcutting. High mortality rates resulting from selfthinning of young even-aged stands probably contributed to the accumulation of organic material in the forest floor (T.R. Crow, North Central Forest Experiment Station, personal communication, 1985). In contrast, the quantity of organic material on the forest floor of the hemlock ecosystem decreased significantly 50 years after clearcutting (Hix and Barnes, 1984). The decreased thickness of the forest floor of the cut hemlock ecosystem was probably due to the more rapid decomposition and incorporation of hardwood foliage than 
hemlock foliage. The Oa of a hemlock ecosystem contains a thick mat of live hemlock roots. Clearcutting caused the death and decomposition of part of this mat.

Although the quantity of organic material was greater on the clearcut sugar maple plots, the level of mineral nutrients per hectare was not significantly different for the cut and uncut plots. Potassium increased 9\%, magnesium increased $7 \%$, and calcium decreased $9 \%$. Clearcutting the hemlock ecosystem brought about significant decreases in the quantity of calcium, magnesium and potassium (Hix and Barnes, 1984). In the uncut hemlock ecosystem approximately 3 times more magnesium and 5 times more calcium is present in the forest floor than in the mineral soil, indicating that the forest floor is a major nutrient storage area. Although the forest floor of the hemlock ecosystem stores large quantities of nutrients, these nutrients are bound in complex, slowly decomposing organic compounds, largely unavailable for utilization by plants. The uncut sugar maple ecosystem contains $72 \%$ less potassium, $58 \%$ less magnesium and $64 \%$ less calcium in the forest floor than the hemlock ecosystem. Because mineralization of hardwood litter is more rapid than for hemlock litter, nutrients are more rapidly available for plant utilization. The sugar maple ecosystem contains 4 to 5 times more calcium, magnesium and potassium in the mineral soil than in the forest floor.

Potassium levels in the upper $30 \mathrm{~cm}$ of mineral soil decreased significantly ( $28 \%$ ) on the clearcut sugar maple plots (Table 5 ). This decrease may be insufficient to cause a potassium deficiency. No published records could be found of potassium deficiency following multiple hardwood rotations. Decreased levels of calcium $(25 \% ; P<0.08)$ and magnesium $(26 \% ; P<0.11)$ also is a trend on the clearcut sugar maple plots. In the hemlock ecosystem, on the other hand, a significant increase in calcium levels occurred on the clearcut plots, and a trend toward increased magnesium was noted. Thus, clearcutting in a hemlock ecosystem increased the level of available nutrients in the mineral soil, whereas clearcutting in the sugar maple ecosystem caused a reduction in the levels of nutrients available to plants, primarily in the upper $30 \mathrm{~cm}$ of mineral soil. If this trend continues, it could be a limiting factor for productivity following additional harvests on the ecosystems dominated by sugar maple.

\section{ACKNOWLEDGEMENTS}

This paper is based on portions of a thesis submitted by the senior author in partial fulfillment of the requirements of the Master of Science in the School of Natural Resources, The University of Michigan, Ann Arbor. Funding by the McIntire-Stennis Cooperative Forestry Research Act (P.L. 87-788) and the Horace H. Rackham School of Graduate Studies of the University of Michigan is gratefully acknowledged. The authors thank the Supervisor of the Ottawa National Forest (USDA Forest Service) for permission to conduct research in 
the Sylvania Recreation Area, and the staff of the Watersmeet District Ranger's Office for their assistance. Thanks to Bill Brodowicz for his assistance with field work.

\section{REFERENCES}

Allison, L.E., 1965. Organic carbon. In: C.A. Black (Editor), Methods of Soil Analysis. Agronomy 9, American Society of Agronomy, Madison, WI, 1367-1378.

Anonymous, 1951. Soil survey staff. Soil survey manual. Agric. Handb. 18, U.S. Government Printing Office, Washington, DC.

Barnes, B.V., 1984. The ecological approach to ecosystem classification. In: D.C. Grey, A.P.G. Schonau and C.J. Schultz (Editors), Proc. Symp. Site and Productivity of Fast Growing Plantations, 30 April-11 May, 1984, Pretoria and Pietermaritzburg, South Africa, pp. 69-89.

Barnes, B.V. and Wagner, W.H., Jr., 1981. Michigan Trees. University of Michigan Press, Ann Arbor, MI, $383 \mathrm{pp}$.

Barnes, B.V., Pregitzer, K.S., Spies, T.A. and Spooner, V.H., 1982. Ecological forest site classification. J. For., 80: 493-498.

Barrett, J.W., 1980. Regional Silviculture of the United States. Wiley, New York, 551 pp.

Broadbent, F.E., 1965. Organic matter. In: C.A. Black (Editor), Methods of Soil Analysis. Agronomy 9, American Society of Agronomy, Madison, WI, pp. 1397-1400.

Conover, W.J., 1980. Practical Nonparametric Statistics. Wiley, New York, 493 pp.

Day, P.R., 1965. Particle fractionation and particle-size analysis. In: C.A. Black (Editor), Methods of Soil Analysis. Agronomy, 9, American Society of Agronomy, Madison, WI, pp. 545-567.

Doonan, C.J. and Hendrickson, G.E., 1986. Groundwater in Gogebic County, Michigan. Geol. Surv., U.S. Department of the Interior, Lansing, MI, $22 \mathrm{pp}$.

Dorr, J.A., Jr. and Eschman, D.F., 1970. Geology of Michigan. University of Michigan Press, Ann Arbor, MI, $476 \mathrm{pp}$.

Eyre, F.H. and Zillgitt, W.M., 1953. Partial cutting in northern hardwoods of the Lake States. USDA For. Serv. Lake States For. Exp. Stn. Tech. Bull. 1076, 124 pp.

Fernald, M.L., 1950. Grey's Manual of Botany (8th Edition). American Book Co., New York, $1632 \mathrm{pp}$.

Goff, F.G., 1967. Upland vegetation. In: C.J. Milfred, G.W. Olsen and F.O. Hole (Editors), Soil Resources and Forest Ecology of Menominee County, Wisconsin. Univ. Wis. Geol. Nat. Hist. Surv. Bull. 85, Soil Ser., 60: 60-90.

Grigal, D.F., 1973. Note on the hydrometer method of particle-size analysis. Minn. For. Res. Notes $245,4 \mathrm{pp}$.

Hix, D.M., 1983. Classification, effects of clearcutting, and management recommendations for forest ecosystems of the Sylvania Recreation Area, Upper Michigan. M.S. Thesis, Univ. of Michigan, Ann Arbor, MI, 207 pp.

Hix, D.M. and Barnes, B.V., 1984. Effects of clearcutting on the vegetation and soil of an eastern hemlock dominated ecosystem, western Upper Michigan. Can. J. For. Res., 14: 914-923.

Hoover, M.D. and Lunt, H.A., 1952. A key for the classification of forest humus types. Soil Sci. Soc. Am. Proc., 16: 368-370.

Jordan, J.K., 1973. A soil resource inventory of the Sylvania Recreation Area. USDA Forest Service, Eastern Region, Ottawa National Forest, Watersmeet Ranger District, 53 pp.

Maissurow, E.E., 1941. The role of fire in the perpetuation of virgin forests in northern Wisconsin. J. For., 39: 201-207.

Marshall, R., 1927. The growth of hemlock before and after release from suppression. Harv. For. Bull. II, 43 pp. 
Meshref, W.M. and Hinze, W.J., 1970. Geologic interpretation of aeromagnetic data in western Upper Peninsula of Michigan. Dep. Nat. Resour. Geol. Surv. Rep. Invest. 12, 25 pp.

Metzger, F.T. and Tubbs, C.H., 1971. The influence of cutting methods on regeneration of secondgrowth northern hardwoods. J. For., 69: 559-564.

Mickel, J.T., 1979. How to know the ferns and fern allies. Brown, Dubuque, IA, 229 pp.

Mühlhäusser, G., Hubner, W. and Stummer, G., 1983. Die Forstliche Standortskarte 1:10,000 nach dem Baden-Württembergischen Verfahren. Mitt. Ver. Forstl. Standortskd. Forstpflanzenzücht., 30: 3-13.

Pregitzer, K.S. and Barnes, B.V., 1984. Classification and comparison of upland hardwood and conifer ecosystems of the Cyrus H. McCormick Experimental Forest, Upper Michigan. Can. J. For. Res., 14: 362-375.

Quesnel, H.J. and Lavkulich, L.M., 1981. Comparison of the chemical properties of forest floors, decaying wood, and fine roots in three ecosystems on Vancouver Island. Can. J. For. Res., 11: 215-217.

Schlenker, G., 1964. Entwicklung des Südwestdeutschland angewandten Verfahrens der forstlichen Standortskunde. In: Standort, Wald und Waldwirtschaft in Oberschwäben, 'Oberschwäbische Fichtenreviere', Stuttgart, pp. 5-26.

Smith, D.M., 1962. The Practice of Silviculture. Wiley, New York, 578 pp.

Solomon, D.S., 1977. The influence of stand density and structure on growth of Northern Hardwoods in New England. USDA For. Ser. Res. Pap. NE-362, 13 pp.

Spies, T.A. and Barnes, B.V., 1985a. A multifactor ecological classification of the northern hardwood and conifer ecosystems of Sylvania Recreation Area, Upper Peninsula, Michigan. Can. J. For. Res., 15: 949-960.

Spies, T.A. and Barnes, B.V., 1985b. Ecological species groups of upland northern hardwoodhemlock forest ecosystems of the Sylvania Recreation Area, Upper Peninsula, Michigan. Can. J. For. Res., 15: 961-972.

Spurr, S.H. and Barnes, B.V., 1980. Forest Ecology (3rd Edition). Wiley, New York, 687 pp.

Thwaite, F.T., 1929. Glacial geology of part of Vilas County, Wisconsin. Trans. Wis. Acad. Sci. Art and Lett., 24: 109-125.

Tubbs, C.H., 1969. Natural regeneration. In: Proc. Sugar Maple Conf., 20-22 August 1968, Michigan Tech. Univ., Houghton, Michigan. U.S.D.A. Forest Service and Lake States Council of Industrial Foresters, pp. 75-81.

Tubbs, C.H., 1977. Northern Hardwoods in the North Central States. USDA For. Ser. Gen. Tech. Rep. NC-39, 29 pp.

Voss, E.G., 1972. Michigan Flora. I. Gymnosperms and Monocots. Cranbrook Inst. Sci. Bull. 55, $488 \mathrm{pp}$.

Westveld, R.H., 1949. Applied Silviculture in the United States. Wiley, New York, 590 pp.

Winget, C.H., Cottam, G. and Kozlowski, T.T., 1965. Species association and stand structure of yellow birch in Wisconsin. For. Sci., 11: 369-383. 